\title{
Coupling hydrological-hydraulic models for extreme flood simulating and forecasting on the North Central Coast of Vietnam
}

\author{
H. Van Lai, N. Van Diep, N. T. Cuong \& N. H. Phong \\ Institute of Mechanics, VAST, Vietnam
}

\begin{abstract}
The North Central Coast of Vietnam is a narrow zone with very complicated topography: mountains in the west, sea in the east. Almost all of the river basins are small, short and sloping. There is very heavy rain that occurs on a large scale and is concentrated in a short period (from 2 to 3 days) every year. In these conditions, the North Central Coast of Vietnam is the part that has a high frequency of big floods and flash floods with monstrous destructive force. The tool for simulating and forecasting these extreme floods is needed for the decision makers. In the framework of the FLOCODS project, supported by the European Commission, there is a tool for this purpose made by coupling the hydrological model MARINE and IMECH 1D hydraulic model. The models have been linked and used for flood simulating and forecasting in the Huong River Basin of Vietnam. The verification and the application of the models prove that they can be used for forecasting, evaluating of flood control measures and planning actions in emergency cases not only for this basin, but also for other river basins in the Central Coast of Vietnam.
\end{abstract}

Keywords: hydrological model, hydraulic model, flood control, river basin, Central Coast of Vietnam.

\section{Introduction}

Vietnam is located in the tropical monsoon area. Therefore, the country often faces natural disasters of various types. In recent years, disasters have continually occurred all over the country, caused vast losses in human life, property, socio-economic and cultural infrastructure as well as environmental degradation. 
The territory of Vietnam is divided into seven economic and sub-climate zones, namely the Northern Mountains, the Red River Delta, the North Central Coast, the South Central Coast, the Central Highlands, the Eastern South and the Mekong river delta.

Vietnam frequently suffers from storms, floods, and other types of natural disasters. So, natural disaster managements in general, flood controls in particular, are important issues for sustainable development in Vietnam. Due to specific climate zones, the flood controls are different for concrete sub-climate zones [1]. Strategy of flood management applied for the Red River Delta zone is: to radically prevent floods, for the Central Coast zone is: adaptation for development and for the Mekong river delta zone is: living with floods.

The flood season in the Central Coast of Vietnam is from September to December. This region is characterized by short and steep river systems with rapid flows. Dyke systems in this region are relatively low or uncompleted. Therefore, floods not only occur on the mainstreams but also spread across the floodplains. So, flood management in the Central Coast of Vietnam is a complicated issue.

In this paper the hydrological and hydraulic models are designed for simulating flood of Huong (perfume) River Basin (HRB) in the Thua Thien Hue province. HRB is one of the main basins in North Central Coast of Vietnam. The center of this basin is Hue city (the ancient capital of Vietnam).

The paper consists of 5 section, include: introduction section, section 2 describes hydrological model MARINE, hydraulic model IMECH_1D and their linkage model LUSHUONG, section 3 and section 4 present verification and application results, and in the last section 5 some future issues of flood management in HRB are presented.

\section{Coupling the hydrological model MARINE and the hydraulic model IMECH_1D}

\subsection{Hydrological model MARINE}

The flood model MARINE (Modélisation de l'Anticipation du Ruissellement et des Inondations pour des évéNements Extrêmes), developed by IMFT (Toulouse, France) [2], is an overland flow model, adapted to the physics of extreme and flash flood. Thank to participating in the FLOCODS European project, the Institute of Mechanics has got the source code of MARINE to use in Vietnam cases.

The model is done by solving mass conservation in each mesh and by calculating the velocity of the surface runoff. The mass conservation equation is the following one (where $\mathrm{V}$ is volume, $\mathbf{u}$ the velocity and $\mathrm{P}_{0}$ the source term modeling precipitation):

$$
\iint_{S} \frac{\partial \mathrm{V}}{\partial \mathrm{t}} \cdot \mathrm{dS}+\oint_{\Gamma} \mathrm{V} \cdot \mathbf{u . n} \cdot \mathrm{d} \Gamma=\iint_{\mathrm{S}} \mathrm{P}_{0}
$$


Surface runoff velocity comes from the diffusive wave equation derived from $\mathrm{St}$ Venant equation:

$$
\|\mathbf{u}\|=\sqrt{\text { slope }} \cdot \frac{H^{2 / 3}}{\text { Manning }}
$$

For modelling infiltration in MARINE, the Green Ampt model has been implemented.

Due to very steep slope of the mountain and hilly areas surround HRB the hydrological model MARINE seems to be an appropriate one for modelling flood in this basin. In application of the MARINE, the DEM of the HRB has been built (fig. 1) and upstream parts of the HRB are divided into 3 parts: the Ta Trach sub-basin, the Huu Trach sub-basin and the Bo sub-basin (fig. 2).

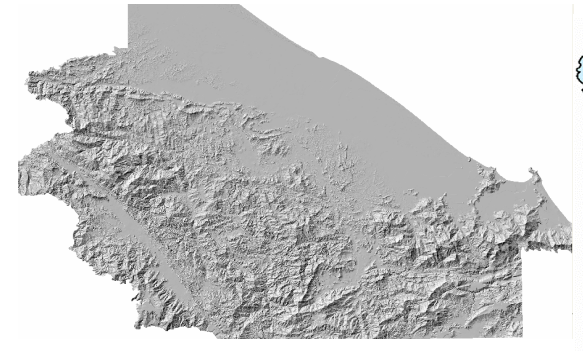

Figure 1: DEM of the HRB. Figure 2: Three sub-basins in upstream of the HRB.

\subsection{Hydraulic model IMECH_1D}

The IMECH_1D model is a one and quasi-two dimensional hydraulic model, developed by the Institute of Mechanics (VAST, Vietnam) for simulating the flows not only in any complex river network, but also in the plains.

Under the assumption of a hydrostatic pressure and uniform distribution of the velocity along the vertical axis, the water flow in a river can be described by the so-called 1D Saint-Venant equations [3]

$$
\begin{gathered}
\frac{\partial A_{s}}{\partial t}+\frac{\partial Q}{\partial x}=0 \\
\frac{\partial Q}{\partial t}+\frac{\partial}{\partial x}\left(\frac{Q^{2}}{A_{f}}\right)+g A_{f} \frac{\partial Z}{\partial x}+g A_{f} \frac{Q|Q|}{K^{2}}=0
\end{gathered}
$$


where $Z$-water elevation, $Q$-discharge, $A_{s}$ and $A_{f}$ - wet cross sectional areas for the main and total flow, $K$-conveyance, $t$-time, $x$-space coordinate.

In storage cells the water levels can be described by the following continuity equation:

$$
\frac{d V}{d t}=\sum q
$$

where $\mathrm{V}$ is the water volume, $\mathrm{q}$ is in- and out- going discharges.

The IMECH_1D has been verified by the 12 testcases in [4]. The validation results of the IMECH_1D in those testcases are similar results in [4].

IMECH_1D has been adapted for simulating flood of the Huong river system. The adapted model consists of 13 rivers with 189 cross-sections and 212 storage cells (fig. 3).

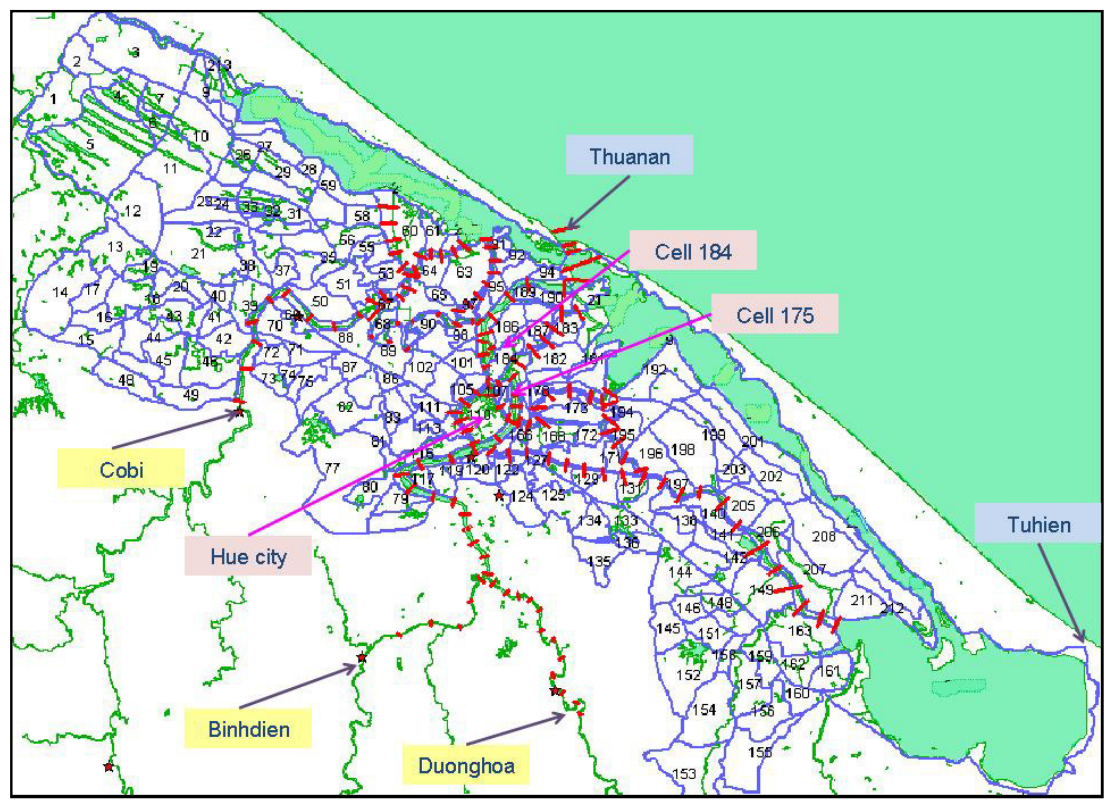

Figure 3: $\quad$ Extended 1D hydraulic model IMECH_1D for the HRB.

\subsection{Coupling MARINE and IMECH_1D}

For flood management in the HRB, the important parameter is the water level at the hydrological station in Hue city (the central point in the basin, see Fig. 3). The extended 1D hydraulic model IMECH_1D is an appropriate one for 
computation of this parameter. In applying the IMECH_1D the following boundary conditions are requisite:

- Discharges at the 3 upstream stations in the Huong river system: The Duonghoa station in the Tatrach river, The Binhdien station in the Huutrach river and the Cobi station in the Bo river,

- Water levels at the 2 outlet in the Tamgiang Cauhai lagoon system: the Thuanan outlet and the Tuhien outlet (see Fig. 3).

The water levels at the outlets are computed by using the tidal model for the sea of the Thua Thien - Hue province. That model is constructed and developed by the Department for Marine Mechanics and Environment of the Institute of Mechanics [5]. We used that model to get water levels at Thuanan and Tuhien outlets.

The discharges at the upstream stations are computed via the MARINE model.

Using the source codes and data of the tidal model, the MARINE and IMECH_1D are linked in one model LUSHUONG (Fig. 4). The input of the model is rainfall information in 7 upstream meteorological stations. The output is discharges in the rivers and water levels in the rivers and in the storage cells.

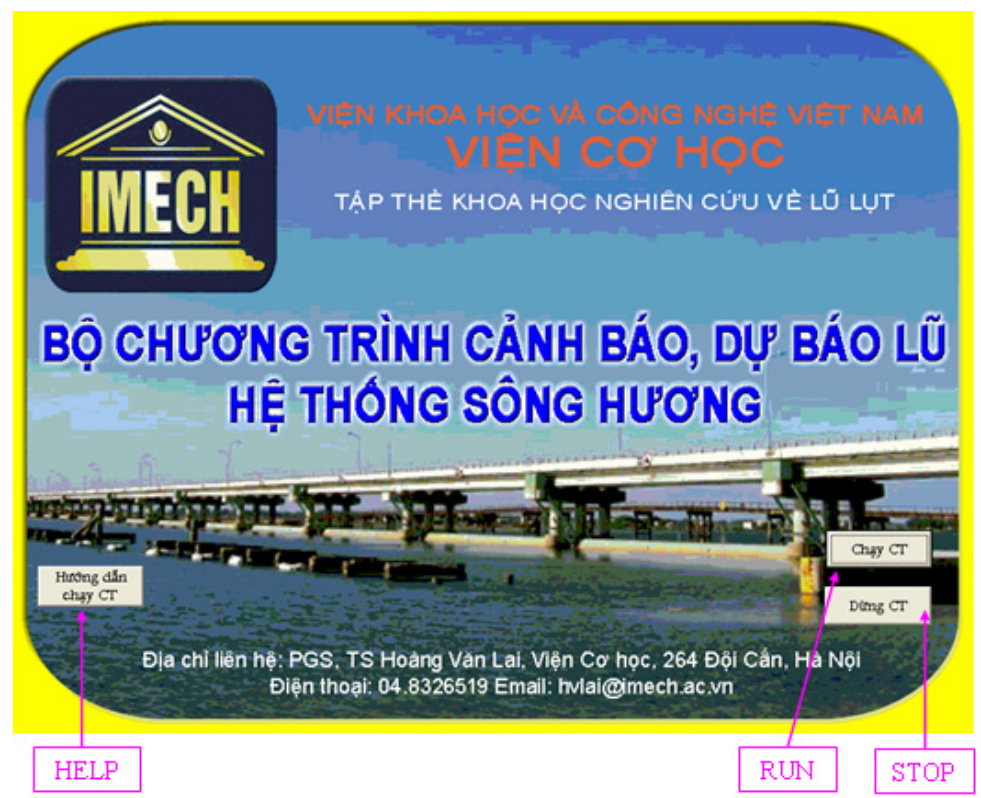

Figure 4: The linkage flood model LUSHUONG for HRB.

LUSHUONG runs very fast, for a 3-day simulation on the notebook VAIO with CPU $2.2 \mathrm{GHz}$, it takes about 6 minutes. 


\section{Verification of the models for the Huong River Basin}

\subsection{Restitution of the historic flood in November 1999}

The historic flood in November 1999 was the very big one. The return period of that flood is $1 \%$. The maximum daily rainfall at Hue city was $978 \mathrm{~mm} /$ day. In the Thua Thien - Hue province, during that flood, 373 people were killed and missing, 99 people injured, 25015 houses were destroyed, 1027 schools collapsed. The total economic loss was about 1761 billion VND.

\section{Flood Restitution 1999}

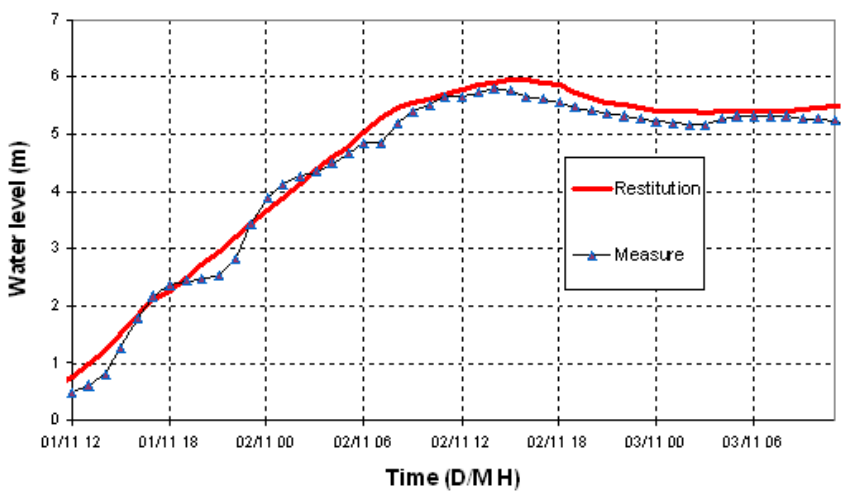

Figure 5: $\quad$ Restituted and measured water levels of the flood, 1999.

\section{Flood Simulation 2004}

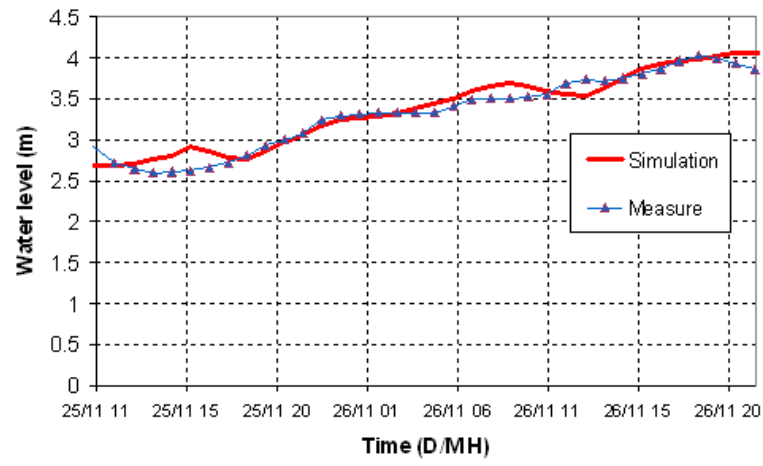

Figure 6: $\quad$ Simulated and measured water levels of the flood, 2004. 
With the collected rainfall data and topographical data (at present time), using LUSHUONG, we have got some simulation results of the historic flood in November 1999. The comparison of the restituted and measured water levels of that flood at the hydrological station in Hue city is shown in the fig. 5.

\subsection{Simulation of the flood in the November 2004}

The flood in the November 2004 was a big one. The total amount rainfall in Hue city was $954 \mathrm{~mm}$. The comparison of the simulated and measured water levels of that flood at the hydrological station in Hue city is shown in fig. 6.

\section{Some results of short term flood forecasts for the Huong river Basin}

With the linkage model LUSHUONG in the years 2005, 2006 and 2007 we tried to do some short-term flood forecasts for the Huong river system. The process of flood forecasts can described as follows:

Step 1. Collecting rainfall data from the meteorological and hydrological stations.

Step 2. Preparing and correcting input data for the model LUSHUONG.

Step 3. Running the model and printing the necessary output data for forecast information of next 12 hours.

Step 4. Analyzing the forecast information. If the information is acceptable, then go to step 5. If the information is not acceptable, then go to step 2.

Step 5. Preparing the forecast bulletin and sending it to the provincial flood control office.

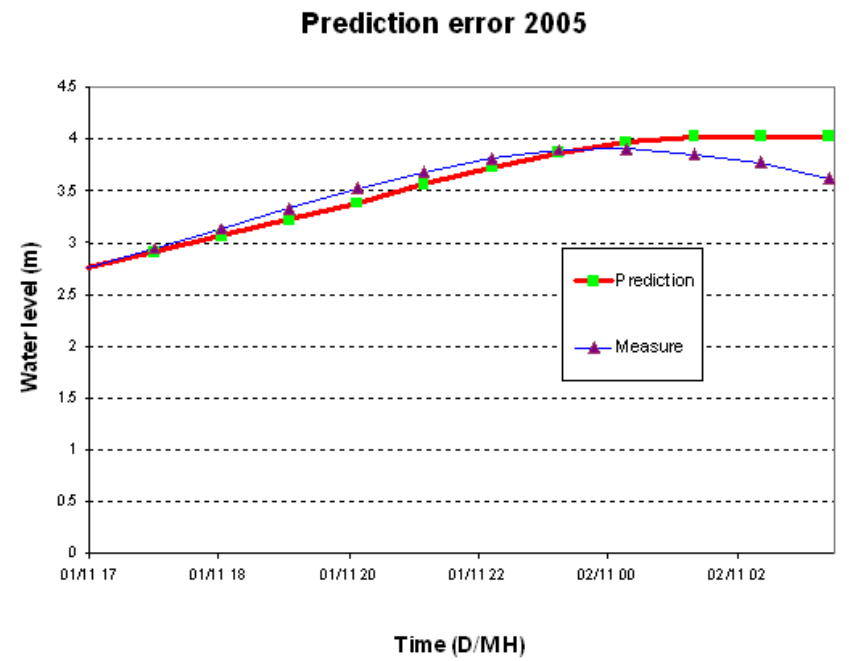

Figure 7: $\quad$ Predicted and measured water levels of the flood, 2005. 
In the flood time, the meteorological and hydrological stations collect new information every hour and we can do the next forecast.

After 12 hours of sending the bulletin, we can get all measured data and the quality of our forecast can be examined.

\subsection{The short term flood forecast in November 2005}

The flood from 29 October to 2 November was the biggest flood in 2005. The cause of that flood was the incidence of heavy rain due to the typhoon N8 (the Kai Tak typhoon). Total amount rainfall in Hue city was $420 \mathrm{~mm}$.

The comparison of the predicted and measured water levels of that flood at the hydrological station in Hue city is shown in the fig. 7.

\subsection{The short term flood forecast in October 2006}

The flood from 30 September to 2 October was the biggest flood in 2006. The cause of that flood is the incidence of heavy rain due to the typhoon N6 (the Xangsane typhoon).

The total amount rainfall in Hue city was $280 \mathrm{~mm}$. The comparison of the predicted and measured water levels of that flood at the hydrological station in Hue city is shown in the fig. 8 .

\section{Prediction error 2006}

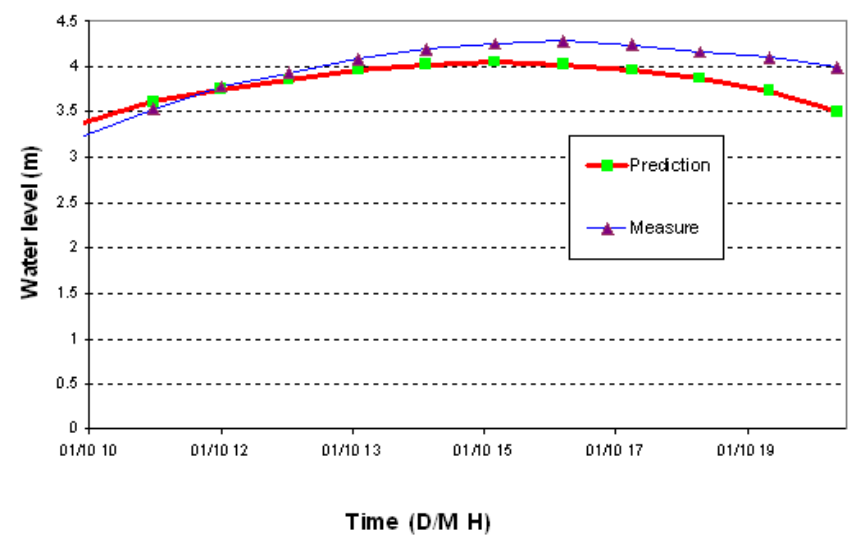

Figure 8: $\quad$ Predicted and measured water levels, 2006.

\subsection{The short term flood forecast in November 2007}

The flood from 10 to 12 November was the biggest flood in 2007. The cause of that flood was the combination of tropical convergence and easterly wind in the high layer. The total amount rainfall in Hue city was $341 \mathrm{~mm}$. 
Prediction error 2007

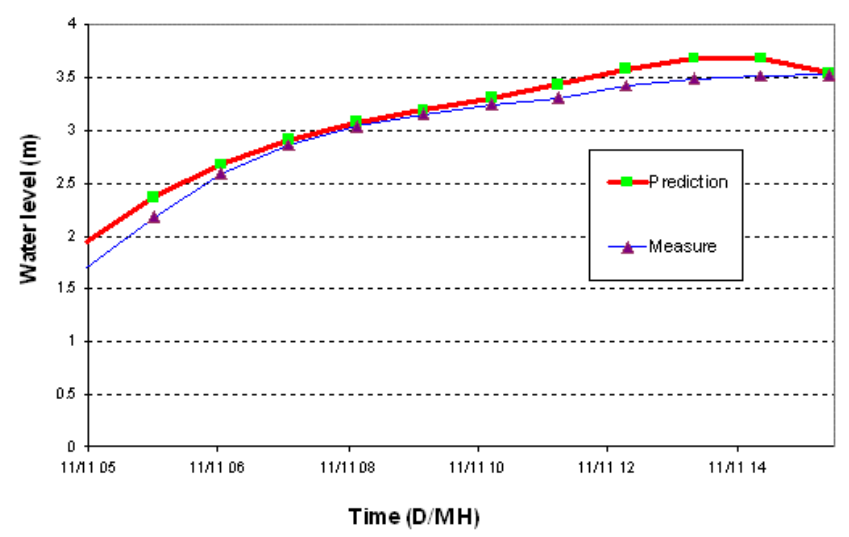

Figure 9: $\quad$ Predicted and measured water levels, 2007.

The comparison of the predicted and measured water levels of that flood at the hydrological station in Hue city is shown in the fig. 9.

\subsection{Inundation in storage cells}

In flood time, many storage cells are inundated. Using the extended 1D hydraulic model IMECH_1D we can simulate inundation process in the storage cells of the basin.

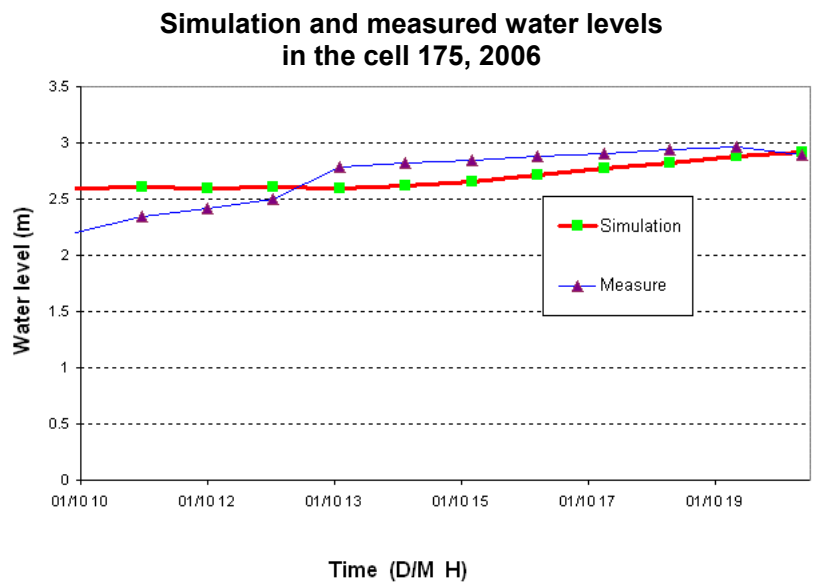

Figure 10: Inundation in the cell 184, 2005. 


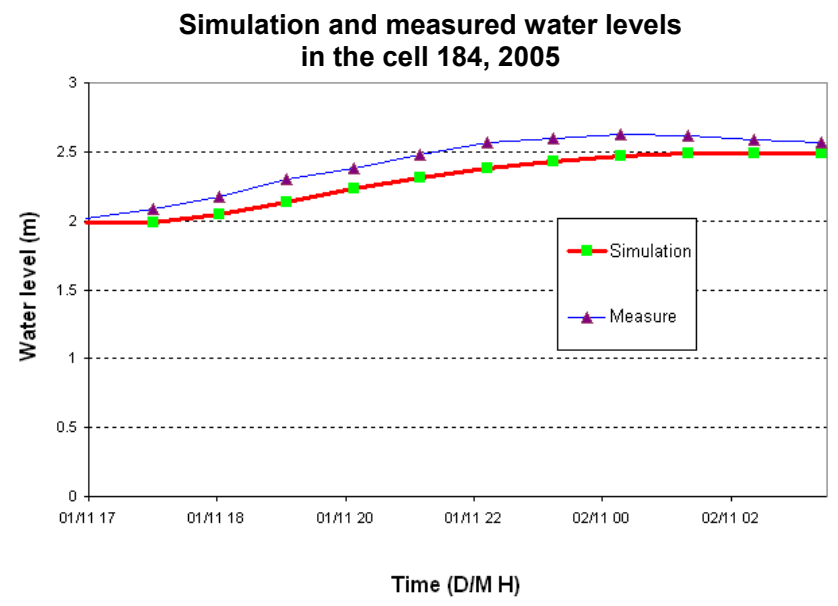

Figure 11: Inundation in the cell 175, 2006.

In recent times the official hydrological station did not exists in the basin and we can collect only some reports from local people about water levels in some places. For example, we have collected some water levels in the cells 184 (see Fig. 3) in the year 2005 and in the cell 175 (see Fig. 3) in the year 2006.

With this information, we can compare simulation and measure results (see Fig. 10 and Fig. 11)

\section{Conclusion}

The struggle with the flood disaster in Vietnam in general and in HRB in particular is very long and difficult work. The first results of application of LUSHUONG show that the hydrological and hydraulic models are useful tools for flood assessment and flood control in the North Central Coast of Vietnam. The model is our effort to contribute for reducing the flood damage in the HRB. In future we need more time and knowledge to improve the models for the HRB. In the first step, we need to set-up rainfall forecast model for HRB, 2D urban flood model for Hue city. In the second steps we need to link rainfall forecast model, hydrological model and hydraulic models for HRB and for other basins in order to contribute to managing and mitigating the climate-change-induced natural flood disaster.

\section{Acknowledgement}

The authors express their gratitude to the National Project KC.08.17/06-10 for the financial supports to prepare this paper. 


\section{References}

[1] Decision No172/2007/QĐ-TTg to approve the National Strategy for Natural Disaster Prevention, Response and Mitigation to 2020, Hanoi, 16 November 2007

[2] V. Estupina-Borrell, D. Dartus, and R. Ababou, Flash flood modeling with the MARINE hydrological distributed model, Hydrol. Earth Syst. Sci. Discuss., 3, 3397-3438, 2006

[3] Cung J.A., Holly F.M. Verwey A. Practical Aspects of Computational River Hydraulics. Pitman Advanced Publishing Program. 1980.

[4] Lebosse A., Codes de Calcul d'ecoulement a surface libre filaire "Lido", "Sara", et "Zero" (version 2). Note de Validation. HE-43/92-95, EDF. 1993.

[5] Do Ngoc Quynh, Nguyen Thi Viet Lien, Calculating Tidal Prediction in the Gulf of Tonkin, Journal of Mechanics, NCNST of Vietnam, T.XVII, N4 (36-41), 1995. 